1 Effects of $\mathbf{2 0}^{\text {th }}$-century settlement fires on landscape structure and forest composition in 2 Eastern Québec, Canada

$4 \quad$ Running title: Effects of settlement fires on landscape structure

6 Authors: Raphaële Terrail ${ }^{1}$, Julie Morin-Rivat ${ }^{2}$ (https://orcid.org/0000-0003-1823-6532),

7 Guillaume de Lafontaine ${ }^{2}$ (https://orcid.org/0000-0001-6889-1733), Marie-Josée Fortin ${ }^{3}$

8 (https://orcid.org/0000-0002-9935-1366), Dominique Arseneault ${ }^{1}$ (https://orcid.org/0000-0002-

$9 \quad \underline{3419-2480})$

$11{ }^{1}$ Département de biologie, chimie et géographie and Centre d'étude de la forêt, Université du

12 Québec à Rimouski, Rimouski, Canada

$13{ }^{2}$ Chaire de Recherche du Canada en Biologie Intégrative de la Flore Nordique, Université du

14 Québec à Rimouski, Rimouski, Canada

$15{ }^{3}$ Department of Ecology \& Evolutionary Biology, University of Toronto, Toronto, Canada

\title{
17 Correspondence
}

18 Dominique Arseneault, Département de biologie, chimie et géographie et Centre d'étude de la

19 forêt, Université du Québec à Rimouski, Rimouski, Canada

20 Email: dominique_arseneault@uqar.ca 


\section{Abstract}

\section{Questions}

25 What role played historical anthropogenic disturbances in modifying the natural fire regime? To

26 which extent have they shaped current forest? Do those have lingering impacts in present-day

27 landscape? Are certain tree species related to former land-use?

\section{Location}

29 Eastern Québec, Canada.

\section{$30 \quad$ Methods}

31 Spatial data on landscape structure, burnt areas, settlements, and forest patches were vectorized 32 on an archival map dating back to 1938. For each landscape class, the total area, the number of 33 polygons, the proportion of the total landscape occupied by the largest polygon were analyzed

34 according to elevation and to the Euclidean distance from the "settlement" polygons. An index of

35 the spatial link between the landscape classes was calculated, based on the proportion of the 36 perimeter of the polygons of each class shared with each of the other classes. A Kolmogorov-

37 Smirnov test for pooled data was used to obtain the frequency distributions of landscape classes 38 as a function of distance. The association between settlement fires and present-day vegetation, 39 and more specifically Populus and Betula stands, was tested by superimposing the most recent 40 ecoforest map on the 1938 land-use map. Distance bands on either side of the 1938 settlement

41 front were delineated to calculate the proportion of each distance class occupied by present-day 42 aspen and birch stands.

\section{Results}

44 Anthropogenic fires generated a recognizable landscape pattern of land-use. Burnt areas were 45 mostly located within $2 \mathrm{~km}$ from a settlement. Most burnings observed on the 1938 map were 
46 human-induced, based on their spatial connection with the settled areas. Lingering impacts of

47 these $20^{\text {th }}$-century fires on present-day forests were identified using the peculiar spatial

48 distribution of tree species. The presence and spatial distribution of aspen in the present-day

49 landscape is tightly associated with previously burnt areas.

\section{Conclusions}

51 Past land-use strongly altered the natural fires regime and associated tree species. Current land-

52 use could potentially lead to increased degraded forest landscapes in a near future.

\section{Keywords}

55 Anthropogenic fires, aspen, boreal forest, land-use, North America, Populus, settlement, spatial

56 landscape structure, temperate forest

\section{7}

\section{Introduction}

60 Uncovering the historical role played by anthropogenic disturbances in shaping current forests

61 remains a crucial issue in paleoecology and forest management (Foster et al. 2003, Higgs et al.

62 2014, Stephens et al. 2019). Paleoecological studies relying on the abundance of charcoal in lake

63 sediments have shown that climate was the main driver of fire regime since the onset of the

64 Holocene at both global (Marlon et al. 2008, Power et al. 2008) and North American (Clifford

65 and Booth 2015, Pederson et al. 2015) scales. However, anthropogenic activities have deeply

66 modified natural fire regimes by increasing fire frequency, which in turn altered terrestrial

67 ecosystems structure and function (Turner and Gardner 2015). This situation has been

68 exacerbated since the industrial revolution and associated human population increase (Marlon et

69 al. 2008, Nowacki and Abrams 2008). 
Human-driven impacts on fire regimes can generally be divided in two phases in

71 temperate and boreal biomes: a rapid and substantial increase in the frequency of anthropogenic

72 fires during the settlement of new territories, followed by a decline, often below the pre-

73 settlement levels. This two-phases pattern has already been documented in the boreal and

74 temperate forests of North America (Weir and Johnson 1998, Bergeron et al. 2006, Hessl et al.

75 2011, Thompson et al. 2013), Eurasia (Lehtonen and Huttunen 1997, Niklasson and Granström

76 2000, Groven and Niklasson 2005), and Patagonia (Veblen et al. 1999). For example, during the

77 European settlement of North America (19 $-20^{\text {th }}$ centuries), massive conversion of forests into

78 farmlands led to a marked increase in fire frequency in surrounding forests (Weir and Johnson

79 1998, Weir et al. 2000, Hessl et al. 2011). The main causes of fire ignition during this period

80 were deforestation using fire, slash-and-burn for agriculture, sparks produced by steam

81 locomotives, and industrial forest exploitation (Blanchet 2003, Pyne 2007). Subsequently, fire

82 frequency has dropped significantly at the wildland-urban interface due to the gradual cessation

83 of forest conversion into farmlands, to greater and better organized efforts for fire suppression

84 (Cardil et al. 2018), and to increased fragmentation of fuels across human-dominated landscapes

85 (Weir and Johnson 1998, Weir et al. 2000, Lefort et al. 2003, Peter et al. 2006, Brose et al. 2013).

86 However, in several human-dominated landscapes, it remains difficult to identify the

87 causes of fire ignition during the last two centuries, whether anthropogenic, climatic, or resulting

88 from the interaction between these two drivers (Pyne 1997, Bowman et al. 2011, Boucher and

89 Grondin 2012, Johnson and Kipfmueller 2016). This may in part result from the lack of spatially

90 explicit data regarding the occurrence of early anthropogenic fires, which might confound our

91 understanding of the landscape structure during the settlement phases. If anthropogenic fires

92 accompanied some settlement episodes, then burnt areas should be spatially connected to settled

93 areas. Indeed, previous studies have suggested that landscapes subject to anthropogenic fires 
94 display diagnostic properties that can be identified. For instance, Cochrane and Laurence (2002)

95 reported that anthropogenic fires in Amazonia represent a typical "fish-bone" edge effect at the 96 settlement front. In the North American and Scandinavian boreal forests, increased fire frequency

97 has been detected directly in the vicinity of human activities during settlement phases (Weir et al.

98 2000, Lefort et al. 2004, Grenier et al. 2005, Wallenius et al. 2005). Similarly,

99 dendrochronological data from Eastern European Russia (Drobyshev et al. 2004) and Patagonia

100 (Mundo et al. 2013, Paritsis et al. 2013) have shown increased correlation between fires and

101 settlements with decreasing distance from the nearest village. Moreover, fire-adapted forests may

102 have subsequently developed following these settlement fires (Weir and Johnson 1998),

103 producing a long-lasting imprint still visible in present-day landscapes in North America (Clark

104 and Royall 1995, Nowacki and Abrams 2008, Munoz and Gajewski 2010, Danneyrolles et al.

105 2016), Eastern Europe (Niklasson et al. 2010), Scandinavia (Niklasson and Drakenberg 2001),

106 and Russia (Wallenius et al. 2005). Such legacies of past fire regimes may have important

107 consequences on the structure, composition, functioning and management options of many

108 present-day and future landscapes (Paristis et al. 2015, Kitzberger et al. 2016, Boulanger et al.

109 2019).

110 In 1938, an aerial survey was conducted to map land-use types at the height of a European

111 settlement episode in the Lower St. Lawrence region, within the southern boreal forest of eastern

112 Canada. Here, we analyze an archival map produced during this survey and provide a spatially

113 explicit reconstruction of the connection between settled and burnt areas. We also test the

114 lingering impact of increased anthropogenic fire on the forest landscape. Specifically, we

115 hypothesize that present-day distributions of the early-successional, fire-adapted trembling aspen

116 (Populus tremuloides Michx.) (Bergeron and Charron 1994) and white birch (Betula papyrifera

117 Marshall) stands reflect the occurrence of settlement fires. Both species have dramatically 
118 increased in abundance after European settlement of the North American boreal and temperate

119 forests (Friedman and Reich 2005, Thompson et al. 2013, Dupuis et al. 2011), and anthropogenic

120 disturbances were probably a major cause of their increase (Danneyrolles et al. 2019).

121

\section{Methods}

124 Study area

125 The study area covers $13,767 \mathrm{~km}^{2}$, bordered by the St. Lawrence River to the North and by the

126 province of New-Brunswick (Canada) and Maine (USA) to the South (Figure 1). The area

127 belongs to the Appalachian geological formation, mainly composed of a sedimentary bedrock

128 that forms low hills with an altitude up to $900 \mathrm{~m}$ (Appendix S1a). Glacial till cover the hill slopes

129 of higher altitudes, while alteration deposits occupy the main valleys and the downslopes

130 (Appendix S1b, Robitaille and Saucier 1998). Postglacial marine deposits from the retreat of the

131 Goldwaith Sea characterize a narrow coastal band. The center of the study area forms a large

132 valley that corresponds to the hydrographic basin of the Matapedia River, which flows

133 southwards (Figure 1). Drainage is generally moderate throughout the study area (Appendix S1c).

134 The climate is temperate continental, with mean annual temperatures varying between -

$13511.4^{\circ} \mathrm{C}$ in January and $18.3^{\circ} \mathrm{C}$ in July (mean $4.4^{\circ} \mathrm{C}$ ) (Rimouski station). Mean annual

136 precipitations reach $958.5 \mathrm{~mm}$, among which $28.5 \%$ are snowfall. The growing season lasts 150

137 days in average and corresponds to $c a .1,500$ degree-days above $5^{\circ} \mathrm{C}$ (ENRC 2019).

138 The study area is located in the transition zone between the temperate and the boreal

139 zones (MRNFP 2004). The forests largely belong to the balsam fir-yellow birch bioclimatic

140 domain, transitioning to the balsam fir-white birch domain further east (Figure 1) (Robitaille and

141 Saucier 1998). Balsam fir (Abies balsamea (L.) P. Mill), yellow birch (Betula alleghaniensis 
142 Britt.), white birch, trembling aspen and white spruce (Picea glauca (Moench).Voss) are

143 common on mesic soil downslopes, while sugar maple (Acer sacharum Marsh), red maple (Acer

144 rubrum L.) and yellow birch mostly occur on hilltops. Black spruce (Picea mariana (P.Mill.)

145 B.S.P.) and northern white-cedar (Thuja occidentalis L.) are found on organic soils. Human-

146 induced modifications of the territory have led to a generalized increase in the abundance of

147 deciduous trees (aspen, maple, and birch) at the expense of conifers (cedar, fir, and spruces)

148 (Boucher et al. 2006, 2009a, b, Dupuis et al. 2011, Terrail et al. 2019). Natural fires were

149 probably uncommon before settlement, with a long rotation period estimated to 1,100 years

150 (Lorimer 1977).

151

152 History of the study area

153 Indigenous peoples in the study region were mainly nomadic (i.e. Algonquians), by contrast with

154 the Iroquoians peoples living closer to current Québec and Montréal cities, who were mainly

155 sedentary (Michaud 2015, Miller 2018). Little is known, however, about the extant of their

156 territory and their land-use. First Europeans settled at the end of the $17^{\text {th }}$ century, although the

157 population actually increased only after 1830 , alongside the development of industrial forest

158 exploitation. Before 1860 , colonists essentially settled in seigniories established before 1760

159 under the French regime along the St. Lawrence River (Fortin et al. 1993). The construction of

160 roads and railways, growth of forest industry, and demographic pressure from more densely

161 populated territories westwards led to the spread of agriculture inland and, more specifically, into

162 the Matapedia River valley after 1880 (Roy 1992). Many settlement campaigns occurred after

1631895 , especially in the 1930s, leading to rapid expansion of land clearing and cultivation.

164 Agricultural expansion and population density of the hinterland (including the Matapedia River 165 valley) peaked around 1940, before the abandonment of several farmlands and the population 
166 exodus to urbanized areas along the coast (Fortin et al. 1993). In the 19 1 th century, the forest

167 industry practiced selective logging of the largest trees near watercourses used for timber floating

168 (Boucher et al. 2009a, b, 2014). With the growth of the pulp and paper industry at the beginning

169 of the $20^{\text {th }}$ century, clearcutting extended inland and intensified in the $1940 \mathrm{~s}$ owing to 170 mechanization.

171

172 The 1938 landscape map

173 The steps of our analysis and associated geodata layers and time steps are conceptualized in the

174 Appendix S2. The 1938 map was produced during a series of aerial surveys carried out in June

175 and July, as part of an inventory of the natural resources in the Lower St. Lawrence region

176 (Hébert 1938). In addition to rivers and lakes, the original document included four landscape

177 classes: "old forest", "young forest", "agriculture", and "burnt". According to the report

178 accompanying the map, these classes corresponded to $\geq 60$-year-old forests, 10 - to 35 -year-old

179 forests, agricultural areas, and burnt areas of less than 10 years, respectively (Hébert 1938). A

180 series of 85 oblique aerial photographs taken concurrently, as well as early land survey records of

181 public lands conducted prior to 1940 (Dupuis et al. 2011, Terrail et al. 2019), allowed us to

182 determine the origin of $80 \%$ of the "young forest" polygons. Because these polygons consistently

183 correspond to burned areas, with typical unburned islands and irregular contours on aerial

184 photographs (Appendix S3), we reclassified all "young forest" as "ancient fire" and changed the

185 "burnt" class to "recent fire". This reclassification is supported by "fire" and "old fire" mentions

186 in early land surveys from the 1900-1940 period as well as by a governmental database of ancient

187 fires dated by fire scars (https:/www.donneesquebec.ca/recherche/fr/dataset/feux-de-

188 foret/resource/8ce4f503-94f8-4041-a395-959c5ade950c). We then combined our "recent fire"

189 and "ancient fire" classes into a more general "total fire" class. Similarly, we replaced the 
190 "agriculture" class as "settlement" because we found that it also included cities, villages and other

191 urban structures. In the original conception of the map (Hébert 1938), this "settlement" class was

192 systematically drawn above the "fire" polygons, thus partially masking and spuriously

193 fragmenting these into several smaller polygons. Hence, the total area of the "fire" polygons is

194 likely underestimated (i.e. masked by settled areas) and their number overestimated. No

195 procedure has allowed for satisfactory reconstruction of the original "fire" polygons.

\section{Landscape structure}

198 The map was scanned using $70-\mathrm{m} \times 70-\mathrm{m}$ pixels (Figure $1 \mathrm{~b}$ ), then georeferenced by using 199 permanent reference lines (e.g. township and provincial borders) and vectorized all polygons of 200 the different landscape classes (ARCGIS 10, ESRI 2011). We first described landscape structure 201 by measuring, for each landscape class, the total area, the number of polygons, the proportion of

202 the total area of the class occupied by the largest polygon, and the proportion of the total

203 landscape occupied by the largest polygon. Elevation was an important factor influencing the 204 spread of the settlement front from the coastal terraces (Fortin et al. 1993). We thus calculated the 205 relative abundance of landscape classes within 100-m elevation bands, between $0 \mathrm{~m}$ and $700 \mathrm{~m}$ 206 altitude. We generated elevation bands by using the digital hypsometric maps provided by the 207 Québec Ministry of Natural Resources (scale 1: 20,000 with 10-m isolines, MRNQ 2000b).

The spatial connection between the "settlement" and "fire" polygons was studied by 209 creating 100-m-wide land bands up to $30 \mathrm{~km}$ away from all "settlement" polygons. We then

210 examined how the "fire" and "forest" areas were distributed according to the distance to the

211 "settlement" class, and measured the shortest Euclidean distance separating each "fire" polygon

212 from the nearest "settlement" polygon. Finally, we evaluated how the "fire" polygons and their 213 cumulative area were distributed on the landscape according to the shortest distance separating 
214 each "fire" polygon from a "settlement" polygon. As an index of the spatial link between the

215 landscape classes, we measured $P_{i j}$, the proportion of the perimeter of the polygons of each class $i$

216 ("settlement", "total fire", "ancient fire", "recent fire", and "forest"), shared with each of the other

217 classes $j$ :

218

$$
P_{i j}=\left[\left(p_{i j} / p_{i}\right) \times 100\right](\text { eq. } 1)
$$

219 where $p_{i j}$ is the total perimeter length shared between polygons of classes $i$ and $j$ in the entire map,

220 and $p i$ is the total perimeter length of class $i$. We used a Kolmogorov-Smirnov test for pooled

221 data (Zar 1999) to test the frequency distributions of landscape classes as a function of distance.

Association between settlement fires and present-day vegetation

224 In order to assess whether present-day fire-adapted forest stands (i.e. aspen and white birch 225 stands) are a legacy of settlement and fire patterns at the peak of settlement, we superimposed the

226 ecoforest map of the Third Decennial Inventory conducted by the Québec Ministry of Natural

227 Resources (1991-2003, MRNQ 2000a) on the 1938 land-use map. Ecoforest mapping of extant

228 Populus and Betula stands relied on the photo-interpretation of aerial photographs $(1: 15,000)$,

229 based on taxa dominance and co-dominance in the forest cover (MRNFQ 2009). Because it was

230 not possible to distinguish trees beyond the genus level from these map data, we validated the

231 forest composition from 1,251 temporary sampling plots inventoried by the Québec Ministry.

232 This analysis indicated that poplar and birch stands were dominated by trembling aspen and

233 white birch, respectively (Appendix S4).

234 Considering that the maximal extent of agricultural territory was reached around 1940

235 (Fortin and Lechasseur 1999), we assessed whether present-day abundance of aspen and birch

236 stands reflects the location and the spatial configuration of the settlement front mapped in 1938.

237 We first positioned the 1938 settlement front at the interface between the largest forest polygon 
238 not fragmented by human activities and the reunion of "settlement" and "fire" polygons directly

239 connected with the early settled coastal sector. We then delineated distance bands (of increasing

240 width from $500 \mathrm{~m}$ to $5 \mathrm{~km}$ ) ranging from $500 \mathrm{~m}$ to $20 \mathrm{~km}$ on either side of the 1938 settlement

241 front to calculate the proportion of each distance class occupied by present-day aspen and birch 242 stands.

243 Aspen and birch stands were superimposed on the 1938 map to test more specifically 244 whether pre-1938 fires and settlement directly influenced the present-day distribution of these 245 forest stands. Because more recent fires may also have contributed to the forest dynamics, we 246 added 1940-2007 "fire" polygons contained in the database of the Forest Fire Protection Agency 247 (SOPFEU, 2018). Note, however, that the older the time period, the less complete and accurate 248 the polygons outline becomes. Similarly, we also added fires older than those mapped in 1938, as 249 reconstructed from early land surveys conducted between the 1820s and the $1930 \mathrm{~s}$. We calculated 250 the frequency of fire observations (number fires mentioned by a surveyor divided by the total 251 number of surveyors' observations) in each $2-\mathrm{km} \times 2-\mathrm{km}$ cell throughout the surveyed territory. 252 The two-km unit was the smallest land unit we could use for this analysis given that land surveys 253 were conducted along range lines spaced by $1.6 \mathrm{~km}$ (i.e. a mile). Settlers later established their 254 farms along these rage lines (Appendix S5). We then conducted a permutation test in order to 255 verify the null hypothesis that aspen and birch stands are randomly distributed relative to the 256 "total fire" (including cells with surveyor's fire mentions), the "settlement", and the union of total 257 fire and settlement landscape classes. The number of stands expected in each of these classes 258 under the assumption of random aspen or birch stands distributions were estimated from 1,000 259 random permutations of the stand centroids within the study area. The confidence intervals of the 260 expected values were determined from the corresponding $2.5^{\text {th }}$ and $97.5^{\text {th }}$ percentiles of the 261 permutations and were compared to the corresponding observed values. This analysis was 
262 repeated after excluding the "young forest" class to confirm that our conclusions are not 263 influenced by the reclassification of "young forest" into "ancient fire" (Appendix S6).

\section{Results}

267 Landscape structure

268 The 1938 landscape reflected the rapid advance of a settlement front inland and along the

269 Matapedia River valley (Figure 1). The "forest" class was dominant, covering 67\% of the total 270 landscape area, while the "settlement" and "total fire" classes accounted for 19\% and 13\%, 271 respectively (Table 1). The "settlement" class dominated along the coast and "forest" was inland, 272 whereas the "fire" class was located at the interface between "settlement" and "forest" classes 273 (Figure 1). Forests were still highly connected, with the largest "forest" polygon occupying 59\% 274 of the total landscape area and $87 \%$ of the total forest area.

275 The spatial structuring of the landscape also depended on altitude (Figure 2a and $b$ ). The 276 "settlement" class occupied the lowest altitudes, with a relative abundance reaching $c a .70 \%$ in 277 the $0-100 \mathrm{~m}$ elevation band, and decreasing steadily to a relative abundance $<1 \%$ above $400 \mathrm{~m}$ in 278 elevation. By contrast, the relative abundance of the "forest" class increased from ca. 30\% below $279100 \mathrm{~m}$, to almost $100 \%$ higher than $600 \mathrm{~m}$. The "ancient fire" and "recent fire" classes occupied 280 an intermediate position, with a maximum relative abundance reaching $20 \%$ between $200 \mathrm{~m}$ and $281300 \mathrm{~m}$ (Appendix S1). The "settlement" class disappeared completely along with the "recent fire" 282 class above $600 \mathrm{~m}$.

$284\left(P_{i j}\right.$ index $)$ illustrates the diagnostic position of the fire polygons at the interface between the 285 "settlement" and "forest" classes (Table 2). Indeed, "total fire" had almost as much perimeter in 
286 common with "settlement" (42\%) as with "forest" (50\%). "Ancient fire" shared a greater 287 perimeter with "settlement" (59\%) than with "forest" (28\%), whereas "recent fire" had a greater 288 perimeter in common with "forest" (61\%) than with "settlement" (31\%). Hence, the "ancient fire" 289 class is found at lower altitude and closer to the St. Lawrence River compared to the "recent fire" 290 class.

291 In 1938, fires were strongly connected to settled areas (Figure 1). More than $70 \%$ of the 292 total burnt area ("ancient fire" plus "recent fire" polygons) was located within $2 \mathrm{~km}$ from a 293 "settlement" polygon (Figure 2c). In comparison, only $42 \%$ of the "forest" area occurred within 4 $294 \mathrm{~km}$ from the nearest "settlement" polygon. In addition, more than $80 \%$ of all "fire" polygons were 295 located (at the shortest distance) within $2 \mathrm{~km}$ from a "settlement" (Figure 2d), and more than 95\% 296 of the total burnt area was included in polygons whose shortest distance to a "settlement" polygon 297 was less than $2 \mathrm{~km}$ (Figure 2e). While "ancient fire" and "recent fire" polygons had a similar 298 frequency distribution according to their shortest distance to a "settlement" polygon $\left(\mathrm{D}_{\text {Kolmogorov- }}\right.$ 299 Smirnov $=0.20, P=0.28)$, "recent fire" distribution was skewed inland compared to "ancient fire" 300 (Figures 1 and 2d).

Association between settlement fires and present-day vegetation

303 The present-day distribution of aspen and birch stands in the landscape was strongly shaped by 304 the 1938 settlement front and associated fire polygons (Appendix S6). The position of the 305 settlement front in 1938 strikingly delineates the zones of highest abundance for aspen and birch 306 stands, respectively (Figure 2f; Figure 3). The transition between the relative abundance of the 307 two stand types across the landscape corresponds precisely to the position of the settlement front 308 in 1938 (Figure 2f). Aspen stands are more abundant towards the coast, behind the settlement 309 front (Figure 3a), whereas birch stands are rather found inland, ahead of the settlement front 
310 (Figure 3b). Permutation tests indicated that centroids of aspen stands are more frequently located

311 inside fire polygons than expected from 1,000 random simulations (Figure 3c) whereas birch

312 stands centroids are less often found within fire polygons than expected from the null distribution

313 (Figure 3d). The fire-aspen connection remains strong, even when considering only the "recent

314 fire" class (Appendix S6) or the reunion of all $19^{\text {th }}$ century and $20^{\text {th }}$ century fire polygons and fire

315 mentions (Appendix S7). Indeed, 44\% of all aspen stands were present in areas that have burnt

316 since the mid-19 $9^{\text {th }}$ century, whereas these burnt areas covered less than $13 \%$ of the total landscape.

317 The high frequency of aspen stands in the seignories settled during the first half of the $19^{\text {th }}$

318 century in the coastal sector along the St. Lawrence River (Appendix S6) suggests that these

319 forest stands can persist for more than 150 years.

\section{Discussion}

323 Connection between settlements and fires

324 Several studies have documented a general increase in fire frequency triggered by the expansion 325 of human activities following European settlement in North America (Pyne 2007). This

326 phenomenon was exacerbated during agricultural expansion in the southern boreal and temperate 327 zones, as previously reported at the margin of the boreal zone in central Canada (Weir and 328 Johnson 1998). Such increase in fire frequency was generally inferred from historical documents 329 (e.g. early land survey archives, early maps and aerial photos) (e.g. Lorimer 1977, 2001, Schulte 330 and Mladenoff 2005, Boucher et al. 2014, 2017, Danneyrolles et al. 2016) and empirical data

331 from field observations (e.g. fire scars) (Drobyshev et al., 2008a, b, Hessl et al., 2011). These 332 sources of information are often fragmentary and seldom allow for a systematic location or an 
333 accurate contour of fires related to European colonization over large geographic areas, thus

334 hindering any attempt at inferring a cause-and-effect relationship between the human presence 335 and fire activity. Interestingly, the archival map used in the present study rigorously shows the 336 extent of fires relative to other landscape classes from a large area of eastern Canada in 1938, at 337 the peak of agricultural expansion and reveals a strong spatial connection between the 338 "settlement" and "fire" landscape classes. We inferred that increasing European settlement during 339 the early $20^{\text {th }}$ century has modified fire activity and landscape structure. Furthermore, we 340 demonstrated that this increase in anthropogenic fires has altered forests and left a lingering 341 imprint on present-day landscape.

342 The spatial connection between European settlement and fires in 1938 likely resulted from 343 burning by the settlers to prepare land for agriculture. During the $19^{\text {th }}$ century and the first half of 344 the $20^{\text {th }}$ century, early settlers cleared the forest for their establishment and usually burnt the 345 logging waste (Blanchet 2003). The presence of smoke plumes on the oblique photos (Appendix 346 S5) and the report of their high prevalence during the 1938 aerial survey (Hébert 1938) are 347 additional indications of the historical widespread use of slash fires in the study region. 348 Moreover, the government inventory report of 1938 strongly emphasized that settlers used fire 349 inconsequentially, and that poorly controlled slash fires regularly escaped to the surrounding 350 forest (Guay 1942). In addition, for all inhabited areas in Québec during the 1906-1941 period, 351 only $5.5 \%$ of the reported fires were associated with lightning strikes, whereas $66.5 \%$ were of 352 human origin (SOPFEU 1909-1941). The deep incisions of the settled land within the forest, 353 following the cadastral plan at the settlement front (Figure 1), probably increased the contact area 354 between settled and forest areas, which, in turn, increased the probability of anthropogenic fires 355 to spread into the remaining forest matrix. The construction of a railway through the Matapedia 
356 River valley between 1871 and 1876 is an additional factor for the occurrence of anthropogenic

357 fires in the late $19^{\text {th }}$ and early $20^{\text {th }}$ centuries (SOPFEU 1909-1941, Blanchet 2003). The steam

358 locomotives let out sparks that ignited fires along the railway by burning the available fuels. This

359 source of ignition, however, would have become negligible after 1914, due to the introduction of

360 locomotives inspections, to improvement of spark arresters, and to a reduction of forest fuel close

361 to the railways (Blanchet 2003).

362 The spatial arrangement of the landscape in 1938 also reflected the progression of the

363 settlement along the elevation gradient from the coast. The fires were mainly located at

364 intermediate altitudes, between the coastal and lowland settled areas along the St. Lawrence

365 River and in the Matapedia River valley, and the forests at higher altitudes in the hinterland. The

366 gradual expansion of settlement, from the seigniories established in the $18^{\text {th }}$ century along the

367 shore of the St. Lawrence to the Matapedia valley, as well as the greater agricultural potential of

368 the soils along the St. Lawrence and in the Matapedia valley in comparison with those of the 369 highlands, could explain this peculiar pattern. The "ancient fire" polygons probably indicate the 370 position of the settlement front around 1900-1925. Their location at lower elevation and at a

371 shorter distance from the coast, compared to the "recent fire" class, indicate a rapid progression

372 of the settlement front to the hinterland between 1900 and 1938. Conversely, the virtual absence

373 of both "ancient fire" and "recent fire" classes within the coastal seigniories probably reflect the 374 much older occupation and forest fuel exhaustion of this territory, as well as the slower progress 375 of the settlement before the beginning of the $20^{\text {th }}$ century (Fortin et al. 1993).

\section{Settlement as an ignition agent}

378 In the transition zone between the boreal and mixedwood forests of northeastern North America, 
379 the pre-settlement disturbance regime was likely dominated by secondary disturbances such as 380 insect outbreaks and windthrow, with a long fire cycle estimated to more than 1,100 years 381 (Lorimer 1977). Consequently, the presettlement forest was strongly dominated by shade-tolerant 382 conifer tree species typical of late successional stages, such as fir, spruces, and cedar, with 383 relatively low occurrence of fire-adapted species, such as aspen and pines (Boucher et al., 2009a, 384 2009b, 2017, Dupuis et al 2011, Thompson et al. 2013, Danneyrolles et al. 2016).

385 Our results suggest that this low incidence of natural fires mainly resulted from unsuitable 386 conditions for fire ignition. Indeed, the occurrence of multiple large fires directly connected to 387 the settlement front combined with a virtual absence of fires distant to the settlement front, 388 indicate that fires were not limited by fuel type or weather conditions, but rather by a low 389 frequency of ignition events. The increase in anthropogenic ignitions at the edge of the settled 390 areas resulted in extremely high burn rates at the peak of colonization. According to the 1938 391 regional forest inventory, fires annually burnt $5 \%$ of the territory. Although this estimate is 392 limited to a short time period, it is similar to the highest values ever reported for the most fire393 prone boreal regions (Weir and Johnson 1998, Héon et al. 2014). This did not preclude 394 interactions between weather conditions and anthropogenic ignitions. Weather has probably 395 influenced the spread of fires ignited by settlers in the study area at the beginning of the $20^{\text {th }}$ 396 century, because this period was particularly prone to large fires across both the commercial and 397 non-commercial eastern Canadian boreal forest (Bergeron et al. 2004, Erni et al. 2017). 398 Nevertheless, human ignition in regions were natural fires are uncommon, is a widespread 399 phenomenon already described from the tropics (Cochrane and Laurence 2002, Morin-Rivat et al. 400 2016) to temperate (Balch et al. 2017) and boreal environments (Achard et al. 2007). Moreover, 401 the low fire incidence following the settlement peak in our study area may be attributed to a 402 decrease in human ignitions, along with organized fire suppression (Cardil et al. 2018), and 
403 possibly the increasing abundance of aspen stands, a fuel type which tends to be avoided by fire

404 (Bernier et al. 2016).

405 Several studies assessing burn rates in the temperate and southern boreal forests have 406 highlighted the difficulty to discriminate between the relative contributions of natural and 407 anthropogenic fires (Bergeron et al. 2004). Our results indicate that studying spatial landscape 408 structure at the time of the settlement could provide useful insights regarding the imprint of 409 anthropogenic fires. The overwhelming proportion of fires connected to the "settlement" 410 polygons (more than $80 \%$ ) lend credence to the critical role of past anthropogenic fires in shaping 411 present-day landscapes.

413 Lingering impacts of anthropogenic fires on present-day forest structure and composition

414 Our results demonstrate that the high occurrence of anthropogenic fires in the early $20^{\text {th }}$ century 415 has altered the forest composition of present-day landscape. However, the trends differed 416 markedly between aspen and white birch. These two light-demanding species have high 417 reproductive output and growth rate and are often reported to increase in abundance following 418 ecological disturbance (Zasada et al. 1992, Bergeron and Charron 1994, Thompson et al. 2013, 419 Boucher et al. 2017). Hence, we initially hypothesized that they would react in a similar way to 420 increasing settlement fires. By contrast, our results strikingly demonstrate that aspen and birch 421 stands display opposite patterns of abundance on either side of the 1938 settlement front (Figure 422 2f; Figure $3 \mathrm{a}$ and $\mathrm{b})$.

The contrasted patterns of current abundance might reflect different responses of each 424 species according to their respective abundance patterns in the $19^{\text {th }}$ century. Reconstruction of the $42519^{\text {th }}$-century forest composition based on early land survey records, indicated that trembling 
426 aspen was rare, while white birch was widespread as a companion species throughout the study 427 area (Dupuis et al. 2011, Terrail et al. 2019). This assertion is supported by forest maps of the 428 early $20^{\text {th }}$ century (Boucher et al. 2009a, 2009b) and the land survey archives from neighboring 429 Maine (Lorimer 1977, Thompson et al. 2013). That said, comparing historical data with the 430 modern forest inventories indicates that white birch and especially aspen are more common in 431 today's landscape than in the $19^{\text {th }}$ century (Dupuis et al. 2011, Terrail et al. 2019). This trend has 432 also been reported in southern boreal (Brown and Simmerman 1986, Bergeron 2000, Boucher et 433 al. 2014, 2017, Danneyrolles et al. 2016) and northern temperate forests (Foster et al. 1998) 434 throughout North America. Aspen-dominated stands are common today behind the settlement 435 front, but virtually absent beyond. We thus infer that aspen frequency increased as a consequence 436 of anthropogenic fires behind the front, but that it could not significantly establish beyond the 437 front in the absence of fires. Conversely, birch stands are now mainly confined beyond the 438 settlement front. We conclude that birch frequency decreased behind the front, while increasing 439 within the forested area ahead of colonization.

This contrasted pattern of species abundance probably reflects the faster postfire 441 establishment of aspen thanks to its sprouting and clonal multiplication, that is its greater 442 competitiveness compared to birch on burnt areas (i.e. behind the settlement front). Trembling 443 aspen benefits from the occurrence of fires across its entire distribution range (Bergeron 2000, 444 Bergeron et al. 2001, Kulakowski et al. 2004). Aspen regeneration by suckering allows this 445 species to establish massively and aggressively after fire (Burns and Honkala 1990). Increased 446 ground temperature induced by fire strongly influences nutrient remobilization in soils 447 (Heinselman 1981), while litter removal also creates favorable conditions for suckers growth 448 (Weir and Johnson 1998). The new suitable environments created by anthropogenic fires 
449 probably prompted a rapid and massive post-fire aspen establishment, likely excluding birch and

450 other taxa. The rapid expansion of aspen behind the settlement front suggests that at least some

451 individuals were already present, although they needed not be dominant. Indeed, aspen produces

452 abundant wind-dispersed seeds that can travel over great distances and readily germinate on burnt 453 substrates (Bergeron 2000).

454 White birch regional abundance has increased since the $19^{\text {th }}$ century (e.g. Dupuis et al.

455 2011, Terrail et al. 2019). Birch-dominated stands are now concentrated in the forested area

456 ahead of the 1938 settlement front. These stands may have been favored by logging activities and

457 spruce budworm (Choristoneura fumiferana [Clem.]) outbreaks, two major drivers of forest

458 disturbance beyond the settlement front. Logging of mature trees creates canopy openings

459 allowing light penetration and ground warming, thus favoring white birch regeneration by

460 seeding. (Burns and Honkala 1990). At least three spruce budworm outbreaks occurred across the

461 study area over the past century (Boulanger and Arseneault 2004). While birch benefits from

462 regular canopy gaps created by spruce budworm, the small forest openings associated with insect

463 outbreaks are inappropriate for massive aspen establishment (Kneeshaw and Bergeron 1999,

464 Bergeron 2000).

465 Mitigating expected deleterious effects of global climate warming on ecosystems is now a

466 worldwide endeavor (IPCC 2018). Understanding how ecosystems will respond to ongoing

467 climate change requires a sound comprehension of the complex interplay between climate,

468 disturbance regimes, and associated biotic responses. For example, our study exemplifies how

469 human activities since the $19^{\text {th }}$ century have deeply altered natural disturbance regimes and

470 associated ecosystems. Based on aspen persistence in the early settled coastal seignories of our

471 study area, as well as in the early settled regions elsewhere in the province of Québec

472 (Danneyrolles et al. 2019), we anticipate a long-lasting impact of these legacies. These and other 
473 anthropogenic land-use changes such as landscape fragmentation along with forest 474 homogenization, both in terms of structure and composition, could modify ecosystem responses 475 to future global warming (Millar et al. 2007, Wang et al. 2015, García-Valdés et al. 2015, 476 Danneyrolles et al. 2019) and complicate efforts to manage forest ecosystems sustainably 477 (Boulanger et al. 2019).

478

$479 \quad$ Funding information

480

481 This study was founded by the Fonds de recherche du Québec Nature et technologies (FRQNT, 482 Canada). J.M.R. acknowledges support from the Macpès Teaching and Research Forest (Canada) 483 and the MITACS Accelerate program (No. IT12145, Canada) and the Northern Environment 484 Research Group BORÉAS (UQAR, Canada).

485

486

\section{Author contributions}

488 RF, DA and MJF conceived the research idea; RF and DA collected data and performed the 489 analyses. RF, with contributions of DA and MJF, wrote the original version of the manuscript; 490 JMR, with contributions of GdL and DA, translated, updated and corrected the manuscript and 491 followed up the submission process; all authors discussed the results and commented on the 492 manuscript.

493

494 Data accessibility 495 
496 Primary data and datasets are stored at Département de biologie, chimie et géographie, Université

497 du Québec à Rimouski, Rimouski, Canada, and could be accessed by following the link:

498 https://doi.org/10.6084/m9.figshare.9992336.v1.

499

500 References

501 Achard, F., Eva, H. D., Mollicone, D., \& Beuchle, R. (2007). The effect of climate anomalies and

502 human ignition factor on wildfires in Russian boreal forests. Philosophical Transactions of the

503 Royal Society B: Biological Sciences, 363. http://doi.org/10.1098/rstb.2007.2203

504 Balch, J. K., Bradley, B. A., Abatzoglou, J. T., Nagy, R. C., Fusco, E. J., \& Mahood, A. L. (2017).

505 Human-started wildfires expand the fire niche across the United States. Proceedings of the

506 National Academy of Sciences, 114, 2946-2951. https://doi.org/10.1073/pnas.1617394114

507 Bergeron, Y. (2000). Species and stand dynamics in the mixed woods of Quebec's southern

508 boreal forest. Ecology, 81, 1500-1516.

509 Bergeron, Y., \& Charron, D. (1994). Postfire stand dynamics in a southern boreal forest

510 (Québec): a dendrochronological approach. Ecoscience, 1, 173-184.

511 Bergeron, Y., et al. (2006). Past, current, and future fire frequencies in Quebec's commercial

512 forests: implications for the cumulative effects of harvesting and fire on age-class structure and

513 natural disturbance-based management. Canadian Journal of Forest Research, 36, 2737-2744.

514 Bergeron, Y., et al. (2004). Fire regimes at the transition between mixedwood and coniferous

515 boreal forest in northwestern Quebec. Ecology, 85, 1916-1932.

516 Bergeron, Y., et al. (2001). Natural fire frequency for the eastern Canadian boreal forest:

517 consequences for sustainable forestry. Canadian Journal of Forest Research, 31, 384-391. 
518 Bernier, P., Gauthier, S., Jean, P.-O., Manka, F., Boulanger, Y., Beaudoin, A., \& Guindon, L.

519 (2016). Mapping Local Effects of Forest Properties on Fire Risk across Canada. Forests, 7(8),

520 157. https://doi.org/10.3390/f7080157

521 Blanchet, P. (2003). Feux de forêt : l'histoire d'une guerre. Montréal, Canada: Trait d'union.

522 Boucher, Y., \& Grondin, P. (2012). Impact of logging and natural stand-replacing disturbances

523 on high-elevation boreal landscape dynamics (1950-2005) in eastern Canada. Forest Ecology \&

524 Management, 263, 229-239.

525 Boucher, Y., et al. (2017). Fire is a strong driver of forest composition than logging in the boreal

526 forest of eastern Canada. Journal of Vegetation Science, 28, 57-68.

527 Boucher, Y., et al. (2014). Land use history (1840-2005) and physiography as determinants of

528 southern boreal forests. Landscape Ecology, 29, 437-450.

529 Boucher, Y., et al. (2009a). Logging history (1820-2000) of a heavily exploited southern boreal

530 forest landscape: insights from sunken logs and forestry maps. Forest Ecology \& Management,

$531258,1359-1368$.

532 Boucher, Y., et al. (2009b). Logging pattern and landscape changes over the last century at the

533 boreal and deciduous forest transition in Eastern Canada. Landscape Ecology, 24, 171-184.

534 Boucher, Y., et al. (2006). Logging-induced change (1930-2002) of a preindustrial landscape at

535 the northern range limit of northern hardwoods, eastern Canada. Canadian Journal of Forest

536 Research, 36, 505- 517.

537 Boulanger, Y., et al. (2019). Climate change will affect the ability of forest management to

538 reduce gaps between current and presettlement forest composition in southeastern Canada.

539 Landscape Ecology, 34, 159-174. https://doi.org/10.1007/s10980-018-0761-6

540 Boulanger, Y., \& Arseneault, D. (2004). Spruce budworm outbreaks in eastern Quebec over the 541 last 450 years. Canadian Journal of Forest Research, 34, 1035-1043. 
542 Bowman, D. M. J. S., et al. (2011). The human dimension of fire regimes on Earth. Journal of

543 Biogeography, 38, 2223-2236.

544 Brose, P. H., et al. (2013). The influences of drought and humans on fire regimes of northern

545 Pennsylvania, USA. Canadian Journal of Forest Research, 43, 757-767.

546 Brown, J.K., \& Simmerman, D.G. (1986). Appraising fuels and flammability in western aspen: a

547 prescribed fire guide. Aspen Bibliography, 3717, 49 pp.

548 Burns, R. M., \& Honkala, B. H. (1990). Silvics of North America: 1. Conifers, 2. Hardwoods.

549 Agriculture Handbook 654. Washington, D. C., USA: United States Department of Agriculture,

550 Forest Service.

551 Cardil, A., Lorente, M., Boucher, D., Boucher, J., \& Gauthier, S. (2018). Factors influencing fire

552 suppression success in the province of Quebec (Canada). Canadian Journal of Forest Research.

553 https://doi.org/10.1139/cjfr-2018-0272

554 Clark, J. S., \& Royall, P. D. (1995). Transformation of a northern hardwood forest by aboriginal

555 (Iroquois) fire: charcoal evidence from Crawford Lake, Ontario, Canada. Holocene, 5, 1-9.

556 Clifford, M. J., \& Booth, R. K. (2015). Late-Holocene drought and fire drove a widespread

557 change in forest community composition in eastern America. Holocene, 25, 1102-1110.

558 Cochrane, M. A., \& Laurance, W. F. (2002). Fire as a large-scale edge effect in Amazonian

559 forests. Journal of Tropical Ecology, 18, 311-325.

560 Danneyrolles, V., et al. (2019). Stronger influence of anthropogenic disturbance than climate

561 change on century-scale compositional changes in northern forests. Nature Communications,

562 https://doi.org/10.1038/s41467-019-09265-Z.

563 Danneyrolles, V., et al. (2016). Pre-industrial landscape composition patterns and post-industrial

564 changes at the temperate-boreal forest interface in western Quebec, Canada. Journal of 565 Vegetation Science, 27, 470-481. 
566 Drobyshev, I., et al. (2008a). Interactions among forest composition, structure, fuel loadings and 567 fire history: a case study of red pine-dominated forests of Seney National Wildlife Refuge, Upper 568 Michigan. Forest Ecology \& Management, 256, 1723-1733.

569 Drobyshev, I., et al. (2008b). Pre- and post-European settlement fire history of red pine 570 dominated forest ecosystems of Seney National Wildlife Refuge, Upper Michigan. Canadian 571 Journal of Forest Research, 38, 2497-2514.

572 Drobyshev, I., et al. (2004). Testing for anthropogenic influence on fire regime for a 600 -year 573 period in the Jaksha area, Komi Republic, East European Russia. Canadian Journal of Forest 574 Research, 34, 2027-2036.

575 Dugas, C. (2017). Population et structure du peuplement. In la ruralité au Québec depuis les états 576 généraux du monde rural (1991) : entre l'action et la recherche, bilan et perspectives. $82^{\mathrm{e}}$ Congrès 577 de l'Acfas, Montréal, mai 2014, 9-30.

578 Dupuis, S., et al. (2011). Change from pre-settlement to present-day forest composition 579 reconstructed from early land survey records in eastern Québec, Canada. Journal of Vegetation 580 Science, 22, 564-575.

581 Environment and Natural Resources Canada (ENRC). (2018). Canadian climate normal 1981582 2010. Retrieved from http://climat.meteo.gc.ca/climate normals/index e.html.

583 Environmental Systems Research Institute. (2011). ArcGis 10. User's manual. Redlands, 584 California, USA.

585 Erni, S., et al. (2017). Spatial and temporal dimensions of fire activity in the fire-prone eastern 586 Canadian taiga. Global Change Biology, 23, 1152-1166.

587 Fortin J.-C., \& Lechasseur, A. (1999). Le Bas-Saint-Laurent. Les régions du Québec. Histoire en 588 bref 1, Sainte-Foy, Canada: Éditions de l'IQRC. 
589 Fortin, J.-C., et al. (1993). Histoire du Bas-Saint-Laurent. Les régions du Québec 5. Québec,

590 Canada: Institut québécois de recherche sur la culture.

591 Foster, D. R., et al. (1998). Land-use history as long-term broad-scale disturbance: regional forest 592 dynamics in central New England. Ecosystems, 1, 96-119.

593 Foster, D. R., et al. (2003). The importance of land-use legacies to ecology and conservation.

594 BioScience, 53, 77-88.

595 Friedman, S. K., \& Reich, P. B. (2005). Regional legacies of logging: departure from 596 presettlement forest conditions in northern Minnesota. Ecological Applications, 15, 726-744.

597 García-Valdés, R., et al. (2015). Evaluating the combined effects of climate and land-use change 598 on tree species distributions. Journal of Applied Ecology, 52, 902-912.

599 Grenier, D. J., et al. (2005). Fire frequency for the transitional mixedwood forest of Timiskaming, 600 Quebec, Canada. Canadian Journal of Forest Research, 35, 656-666.

601 Groven, R., \& Niklasson, M. (2005). Anthropogenic impact on past and present fire regimes in a 602 boreal forest landscape of southeastern Norway. Canadian Journal of Forest Research, 35, 27196032726.

604 Guay, J. E. (1942). Inventaire des ressources naturelles du comté municipal de Rimouski : 605 section forestière. Québec, Canada: Ministère de l'Industrie et du Commerce, et Ministère des 606 Terres et Forêt, de la Chasse et de la Pêche du Québec.

607 Hébert, A. D. (1938). Rapport concernant les opérations aériennes de Val Brillant : Comté de 608 Matapédia. Fonds Arsène Hébert, P62. Québec, Canada: Bibliothèque et Archives nationales du 609 Québec.

610 Heinselman, M. L. (1981). Fire and succession in the conifer forests of northern North America. 611 In D. C. West., et al. (Eds.), Forest succession: concepts and application (pp. 374-405). Springer 612 Advanced Texts in Life Science. New York, USA: Springer. 
613 Héon, J., et al. (2014). Resistance of the boreal forest to high burn rates. Proceedings of the

614 National Academy of Sciences of the USA, 111, 13888-13893.

615 Hessl, A. E., et al. (2011). Fire history from three species on a central Appalachian ridgetop.

616 Canadian Journal of Forest Research, 41, 2031-2039.

617 Higgs, E., et al. (2014). The changing role of history in restoration ecology. Frontiers in Ecology

618 \& the Environment, 12, 499-506.

619 Kitzberger, T., et al. (2016). Fire-vegetation feedbacks and alternative states: common 620 mechanisms of temperate forest vulnerability to fire in southern South America and New Zealand.

621 New Zealand Journal of Botany, 54, 247-272.

622 Kneeshaw, D. D., \& Bergeron, Y. (1999). Spatial and temporal patterns of seedling and sapling

623 recruitment within canopy gaps caused by spruce budworm. Ecoscience, 6, 214-222.

624 Kulakowski, D., et al. (2004). The persistence of quaking aspen (Populus tremuloides) in the

625 Grand Mesa area, Colorado. Ecological Applications, 14, 1603-1614.

626 IPCC. (2018). Global Warming of $1.5{ }^{\circ} \mathrm{C}$. Summary for Policymakers. Retrieved from 627 http://www.ipcc.ch/report/sr15/.

628 Johnson, L. B., \& Kipfmueller, K. F. (2016). A fire history derived from Pinus resinosa Ait. for 629 the Islands of Eastern Lac La Croix, Minnesota, USA. Ecological Applications, 26, 1030-1046.

630 Lefort, P., et al. (2004). Recent fire regime (1945-1998) in the boreal forest of western Québec.

631 Ecoscience, 11, 433-445.

632 Lefort, P., et al. (2003). The influence of fire weather and land use on the fire activity of the Lake 633 Abitibi area, Eastern Canada. Forest Science, 49, 509-521.

634 Lehtonen, H., \& Huttunen, P. (1997). History of forest fires in eastern Finland from the fifteenth 635 century AD - The possible effects of slash-and-burn cultivation. Holocene, 7, 223-228.

636 Lorimer, C. G. (2001). Historical and ecological roles of disturbance in eastern North American 
637 forests: 9,000 years of change. Wildlife Society Bulletin, 29, 425-439.

638 Lorimer, C. G. (1977). The presettlement forest and natural disturbance cycle of Northeastern 639 Maine. Ecology, 58, 139-148.

640 Marlon, J. R., et al. (2008). Climate and human influences on global biomass burning over the 641 past two millennia. Nature Geoscience, 1, 697-702.

642 Michaud, G. (2015). Les Autochtones de la rive sud du Saint-Laurent, entre Pointe-Lévis et la 643 Mitis. Histoire Québec, 21, 10-13.

644 Millar, C. I., et al. (2007). Climate change and forests of the future: Managing in the face of 645 uncertainty. Ecological Applications, 17, 2145-2151.

646 Miller, J.R. (2018). Skyscrapers Hide the Heavens. Toronto, Canada: University of Toronto Press.

647 Ministère des Ressources Naturelles et de la Faune (MRNFQ). (2009). Normes de cartographie 648 écoforestière. Troisième inventaire écoforestier. Québec, Canada: Direction des Inventaires 649 Forestiers.

650 Ministère des Ressources naturelles et de la Faune (MNRF). (2007). Normes d'inventaire 651 forestier, placettes-échantillons temporaires. Québec, Canada Direction des inventaires forestiers. 652 Ministère des Ressources Naturelles, de la Faune et des Parcs (MRNFP). (2004). Portrait 653 forestier de la région du Bas-Saint-Laurent. Québec, Canada: Direction régionale du Bas-Saint654 Laurent.

655 Ministère des Ressources Naturelles du Québec (MRNQ). (2000a). Système d'information 656 écoforestier 3ème inventaire décennal (SIEF). Québec, Canada: Forêt Québec, Direction des 657 inventaires forestiers.

658 Ministère des Ressources Naturelles du Québec (MRNQ). (2000b). Carte topographique 659 numérique du Québec l/20 000. Québec, Canada: Photocartothèque québécoise.

660 Morin-Rivat, J., et al. (2016). High spatial resolution of late-Holocene human activities in the 
661 moist forests of central Africa using soil charcoal and charred botanical remains. The Holocene, 662 26, 1954-1967.

663 Mundo, I.A., Wiegand, T., Kanagaraj, R., \& Kitzberger, T. (2013). Environmental drivers and 664 spatial dependency in wildfire ignition patterns of northwestern Patagonia. Journal of 665 Environmental Management, 123, 77-87.

666 Munoz, S. E., \& Gajewski, K. (2010). Distinguishing prehistoric human influence on late667 Holocene forests in southern Ontario, Canada. Holocene, 20, 967-981.

668 Niklasson, M., et al. (2010). A 350-year tree-ring fire record from Bialowieza Primeval Forest, 669 Poland: implications for Central European lowland fire history. Journal of Ecology, 98, 13196701329.

671 Niklasson, M., \& Drakenberg, B. (2001). A 600-year tree-ring fire history from Norra Kvills 672 National Park, southern Sweden: implications for conservation strategies in the hemiboreal zone. 673 Biological Conservation, 101, 63-71.

674 Niklasson, M., \& Granström, A. (2000). Numbers and sizes of fires: Long-term spatially explicit 675 fire history in a Swedish boreal landscape. Ecology, 81, 1484-1499.

676 Nowacki, G. J., \& Abrams, M. D. (2008). The demise of fire and "mesophication" of forests in 677 the eastern United States. BioScience, 58, 123-138.

678 Paritsis, J., Veblen, T. T., \& Holz, A. (2015). Positive fire feedbacks contribute to shifts from 679 Nothofagus pumilio forests to fire-prone shrublands in Patagonia. Journal of Vegetation Science, $680 \quad 26,89-101$.

681 Paritsis, J., Holz, A., Veblen, T. T., \& Kitzberger, T. (2013). Habitat distribution modeling 682 reveals vegetation flammability and land use as drivers of wildfire in SW Patagonia. Ecosphere, $6834,53$. 
684 Parmesan, C., et al. (2005). Empirical perspectives on species borders: from traditional 685 biogeography to global change. Oikos, 108, 58-75.

686 Pederson, N., et al. (2015). Climate remains an important driver of post-European vegetation 687 change in the eastern United States. Global Change Biology, 21, 2105-2110.

688 Peter, B., et al. (2006). Fire risk and population trends in Canada's wildland-urban interface. In 689 K. G. Hirsch and P. Fulgem, Technical coordinators (Eds.), Canadian wildland fire strategy: 690 Background synthesis, analyses, and perspectives (pp. 37-48). Canadian Council of Forest 691 Ministers. Edmonton, Canada: Natural Resources Canada.

692 Power, M. J., et al. (2008). Changes in fire regimes since the Last Glacial Maximum: an 693 assessment based on a global synthesis and analysis of charcoal data. Climate Dynamics, 30, $694887-907$.

695 Pyne, S. J. (2007). Awful splendour: A fire history of Canada. Toronto, Canada: University of 696 British Colombia Press.

697 Pyne, S. J. (1997). Fire in America: a cultural history of wildland and rural fire. Washington, 698 USA: University of Washington Press.

699 Robitaille, A., \& Saucier, J.-P. (1998). Paysages régionaux du Québec méridional. Québec, 700 Canada: Gouvernement du Québec, Ministère des Ressources Naturelles, Les publications du 701 Québec.

702 Roy, L. (1992). La colonisation dans la vallée de la Matapédia de 1850-1900: le rôle du clergé et 703 des compagnies forestières. Revue d'Histoire du Bas-St-Laurent, 16, 3-7.

704 Schulte, L. A., \& Mladenoff, D. J. (2005). Severe wind and fire regimes in northern forests: 705 historical variability at the regional scale. Ecology, 86, 431-445.Société de Protection des Forêts 706 contre les Feux (SOPFEU). (2018). Retrieved from https://sopfeu.qc.ca/.

707 Société de Protection des Forêts contre les Feux (SOPFEU). (1909-1941). Rapport annuel du 
708 ministre des Terres et Forêts du Québec. Documents de la Session. Québec, Canada: Archives de 709 l'Université du Québec à Rimouski.

710 Stephens, L., et al. (2019). Archaeological assessment reveals Earth's early transformation 711 through land use. Science, 365(6456), 897-902. https://doi.org/10.1126/science.aax1192.

712 Terrail, R., et al. (2019). Reorganization of tree communities over the last century in the northern 713 hardwoods of eastern Canada. Applied Vegetation Science. http://doi.org/10.1111/avsc.12449.

714 Thompson, J. R., et al. (2013). Four centuries of change in northeastern United States forests. 715 PLOS ONE, 8, e72540.

716 Turner, M. G., \& Gardner, R. H. (2015). Landscape Ecology in Theory and Practice. New York, 717 USA: Springer.

718 Veblen, T. T., et al. (1999). Fire history in northern Patagonia: the roles of humans and climatic 719 variation. Ecological Monographs, 69, 47-67.

720 Wallenius, T. H., et al. (2005). Fire history and forest age distribution of an unmanaged Picea 721 abies dominated landscape. Canadian Journal of Forest Research, 35, 1540-1552.

722 Wang, W. J., et al. (2015). Importance of succession, harvest, and climate change in determining 723 future composition in U.S. central hardwoods forests. Ecosphere, 6, 227.

724 Weir, J. M. H., \& Johnson, E. A. (1998). Effects of escaped settlement fires and logging on forest 725 composition in the mixedwood boreal forest. Canadian Journal of Forest Research, 28: 459-467.

726 Weir, J. M. H., et al. (2000). Fire frequency and the spatial age mosaic of the mixed-wood boreal 727 forest in western Canada. Ecological Applications, 10, 1162-1177.

728 Zar, J. H. (1999). Biostatistical analysis $4^{\text {th }}$. Upper Saddle River, USA: Prentice Hall.

729 Zasada, J. C., et al. (1992). The reproductive process in boreal forest trees. In R. L. H. H. Shugart

$730 \&$ G. B. Bonan (Eds.), A systems analysis of the boreal forest. Cambridge, UK: Cambridge 731 University Press. 
Table 1. Metrics of the 1938 landscape.

\begin{tabular}{lllllll}
\hline Class & $\begin{array}{l}\text { Proportion of the } \\
\text { total landscape } \\
(\%)\end{array}$ & $\begin{array}{l}\text { Perimeter } \\
(\mathrm{km})\end{array}$ & $\begin{array}{l}\text { Area } \\
\left(\mathrm{km}^{2}\right)\end{array}$ & $\begin{array}{l}\text { Nb of } \\
\text { polygons }\end{array}$ & $\begin{array}{l}\text { Proportion of the largest } \\
\text { polygon }\end{array}$ \\
& & & & & $\begin{array}{l}\text { \% of the } \\
\text { class area }\end{array}$ & $\begin{array}{l}\% \text { of the } \\
\text { total } \\
\text { landscape }\end{array}$ \\
\hline Settlement & 19 & 4987 & 2605 & 143 & 74 & 14 \\
Ancient & 4 & 1222 & 590 & 109 & 22 & 2 \\
fire & & & & & & \\
Recent fire & 9 & 2047 & 1153 & 89 & 21 & 1 \\
Total fire & 13 & 3127 & 1729 & 199 & 15 & 2 \\
Forest & 67 & 6230 & 9189 & 423 & 87 & 59 \\
$\begin{array}{l}\text { River/lake } \\
\text { Total }\end{array}$ & 100 & 1372 & 228 & 489 & 8 & 0 \\
734 & 15716 & 13751 & 1452 & & \\
\hline
\end{tabular}

735

736 Table 2. Perimeter in common $\left(P_{i j}\right.$ index) among the 1938 landscape classes in the study area.

\begin{tabular}{|c|c|c|c|c|c|c|c|c|}
\hline$i$ class $(\%)$ & $\begin{array}{l}j \text { class } \\
\text { Settlement }\end{array}$ & Fire & & & Forest & Lake & Shore & $\begin{array}{l}\text { Outer } \\
\text { limits }\end{array}$ \\
\hline & & Ancient & Recent & Total & & & & \\
\hline Settlement & - & 14 & 13 & 27 & 65 & 4 & 3 & 1 \\
\hline Total fire & 42 & - & - & - & 50 & 5 & 0 & 3 \\
\hline Ancient fire & 59 & - & - & - & 28 & 8 & 0 & 0 \\
\hline Recent fire & 31 & - & - & - & 61 & 3 & 0 & 1 \\
\hline Forest & 52 & 5 & 20 & 25 & - & 16 & 1 & 6 \\
\hline
\end{tabular}


a)
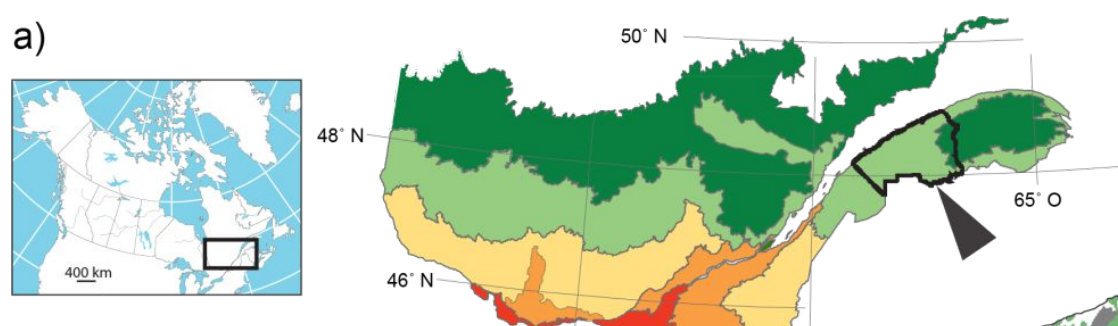

Balsam fir-white birch

Balsam fir-yellow birch

Maple-yellow birch

Maple-linden

Maple-hickory

b)

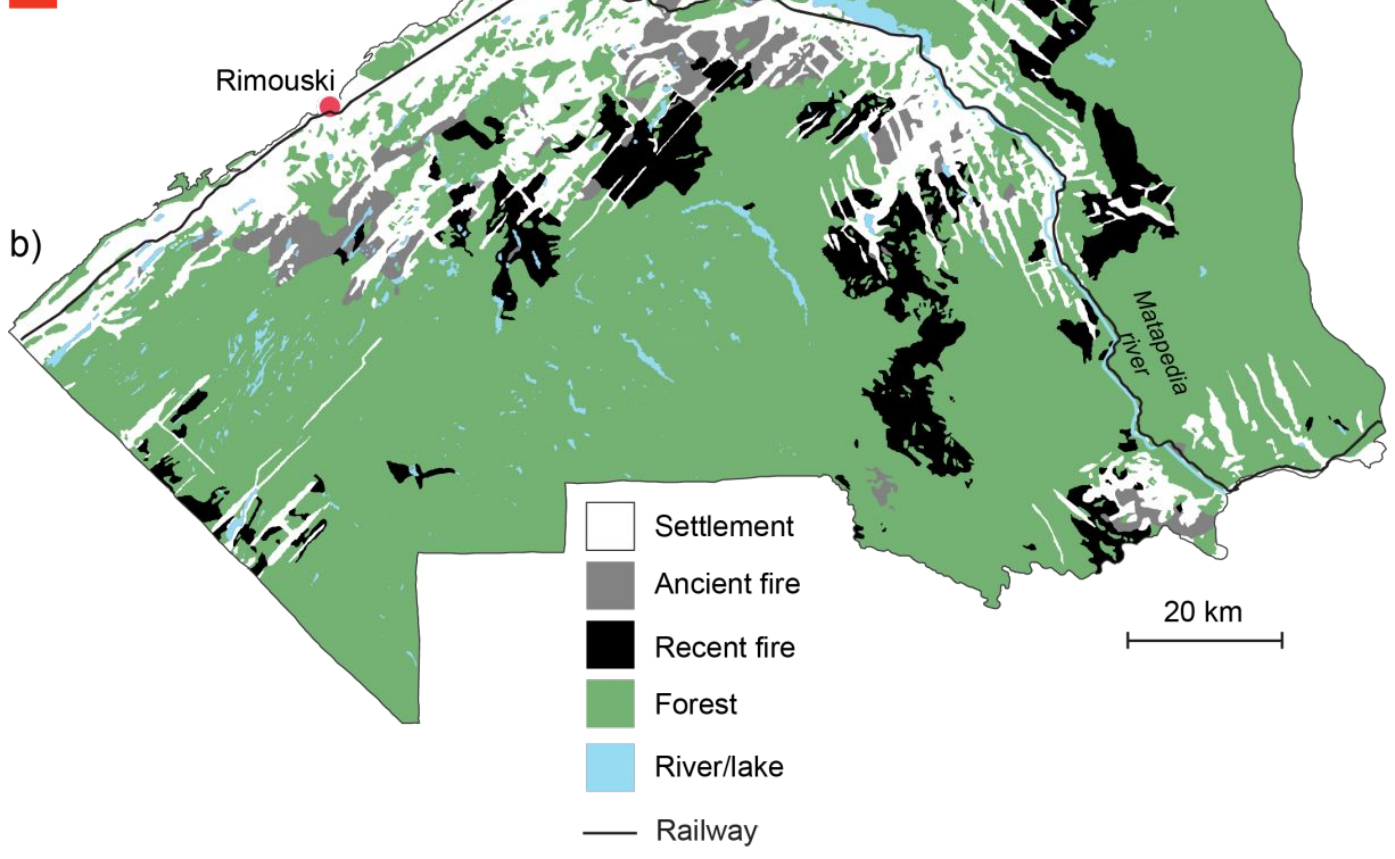

739 Figure 1. Location of the study area in the Lower St. Lawrence region in eastern Québec: (a) the bioclimatic zones

740 in Southern Québec; (b) Land-use types based on the 1938 archival map (Bibliothèque et Archives nationales du

741 Québec, ref. ANQ-A16-P5_1938). "Ancient fire" correspond to 10- to 35-year-old forests (1903-1928) and "recent

742 fire" to burnt areas of less than 10 years (1928-1938). 

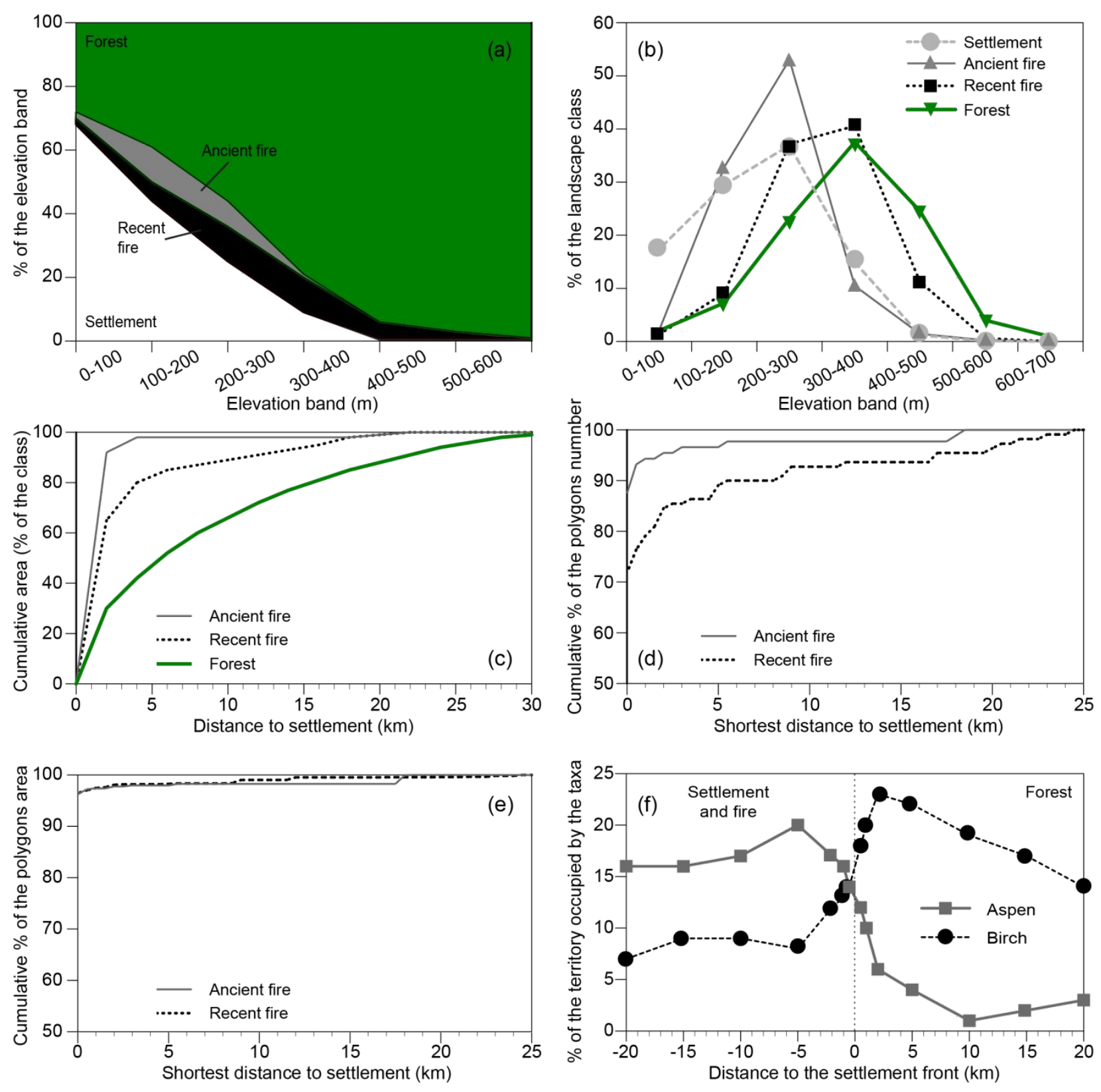

745 Figure 2. The spatial structure of the Lower St. Lawrence landscape in 1938 and its association with explanatory

746 variables. (a) Proportion of each elevation band occupied by each landscape class. (b) Proportion of the total area of

747 each landscape class occupying each elevation band. (c) Cumulative area of the "fire" and "forest" classes in

748 successive 100-m-wide bands surrounding each "settlement" polygon. (d) Cumulative proportion of the total number

749 of "fire" polygons at increasing shortest distance to a "settlement" polygon, and (e) cumulative proportion of total

750 area of "fire" polygons at increasing shortest distance to a "settlement" polygon. (f) Spatial distribution of present-

751 day aspen and birch stands as a function of the distance to the 1938 settlement front. 


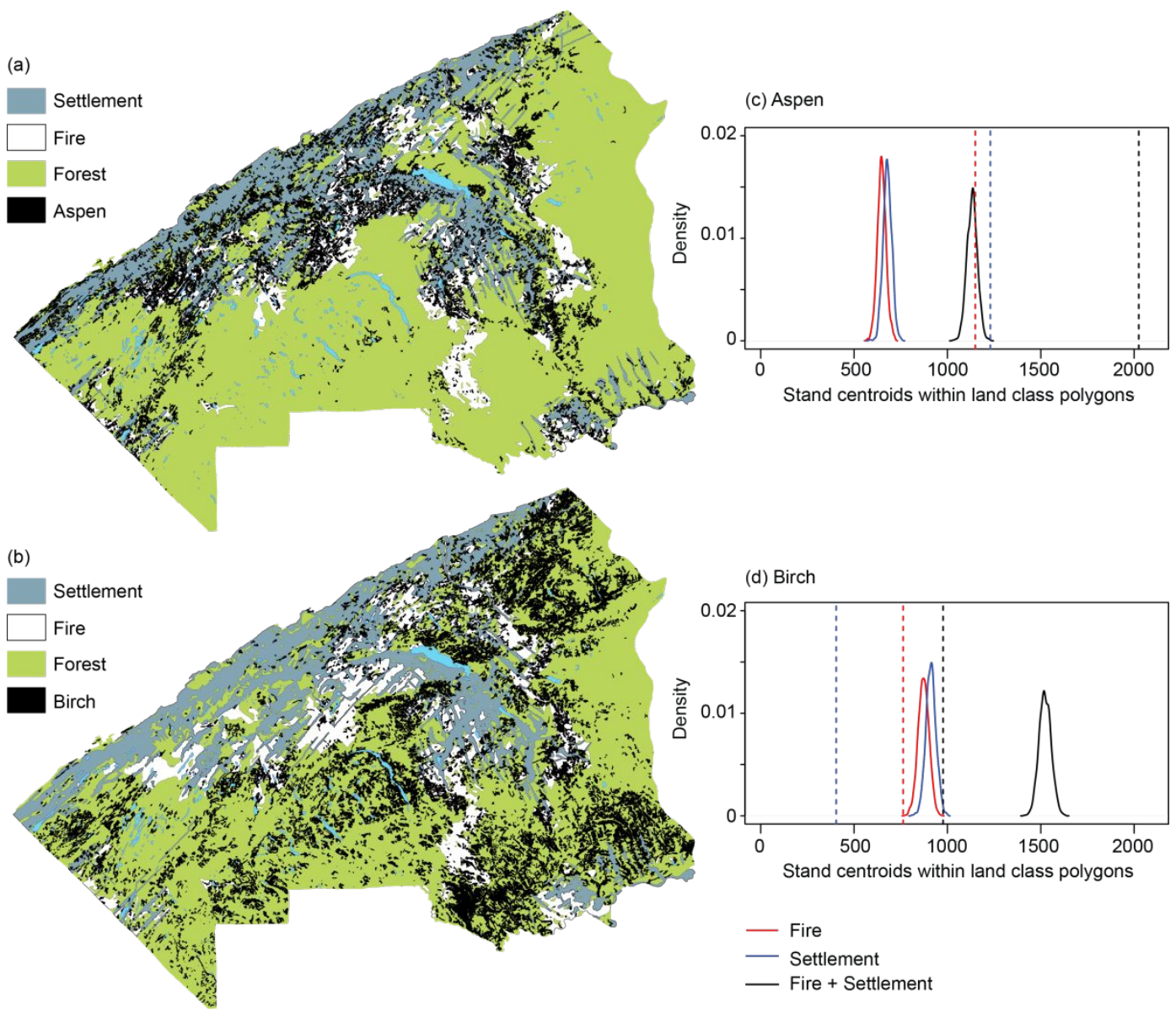

753 Figure 3. (a, b) Distribution of (a) aspen and (b) birch stands (ecoforest maps from the Ministry of Natural

754 Resources, MRNQ 2000a) in relation with the landscape structure classes of the 1938 map. (c, d) Simulated and

755 observed number of aspen (c) and birch (d) stands centroids tallied within land class polygons (fire, settlement).

756 Frequency distributions indicate the number of stand centroids for aspen $(\mathrm{n}=3,586)$ and birch $(\mathrm{n}=4,822)$ stands

757 falling within each land class polygon over 1,000 random permutations. Vertical dotted lines indicate the number of

758 observed stands actually recorded within each land class polygon. 


\section{List of appendices}

762 Appendix S1. Maps of altitude (a), surficial deposits (b) and drainage classes (c) across the study area.

764 Appendix S2. Diagram showing the temporal and conceptual relationships between the georeferenced layers used in 765 this study.

766

767 Appendix S3. Archive photo illustrating the landscape classes mapped from the 1938 aerial survey in the hinterland 768 of the Lower St. Lawrence region (Québec, Canada).

769

770

Appendix S4. Validation of the mapped ecoforest polygons dominated by Populus and Betula taxa from the associated field plots of the Third Decennial Inventory of the Québec Ministry of Natural Resources.

772

773 Appendix S5. Archive photos illustrating typical slash fires during the settlement in the hinterland of the St.

774 Lawrence region (Québec, Canada): (a) oblique aerial photograph taken at the time of the mapping of the study area 775 in 1938 (Bibliothèque et Archives nationales du Québec, E21, P112).

776

777

Appendix S6. Comparison of simulated and observed numbers of aspen stand centroids tallied within all fire 778 polygons (as shown in Fig 3c; blue curve) with the number tallied when considering only the "recent fire" class.

779

780 Appendix S7. The spatial distribution of fire, aspen and birch in the Lower St. Lawrence region (Québec, Canada) 781 (ecoforest maps from the Ministry of Natural Resources, MRNQ 2000a) in relation with the landscape structure 782 classes of the 1938 map.

783

784

785 Summary for the expanding entries

786 Using an archival map dated to 1938 and other spatial data, this study showed that anthropogenic 
787 fires generated a recognizable landscape pattern of land-use in Eastern Québec, Canada.

788 Lingering impacts of $20^{\text {th }}$-century fires on present-day forests were identified using the peculiar

789 spatial distribution of tree species. Specifically, the presence and spatial distribution of aspen on

790 present-day landscape is tightly associated with previously burnt areas.

791

792 Chosen image for the expanding entries

793 Figure 1 (1938 map). 
Supporting information to the paper

Terrail, R. et al. Effects of $20^{\text {th }}$-century settlement fires on landscape structure and forest composition in Eastern Québec, Canada. Journal of Vegetation Science

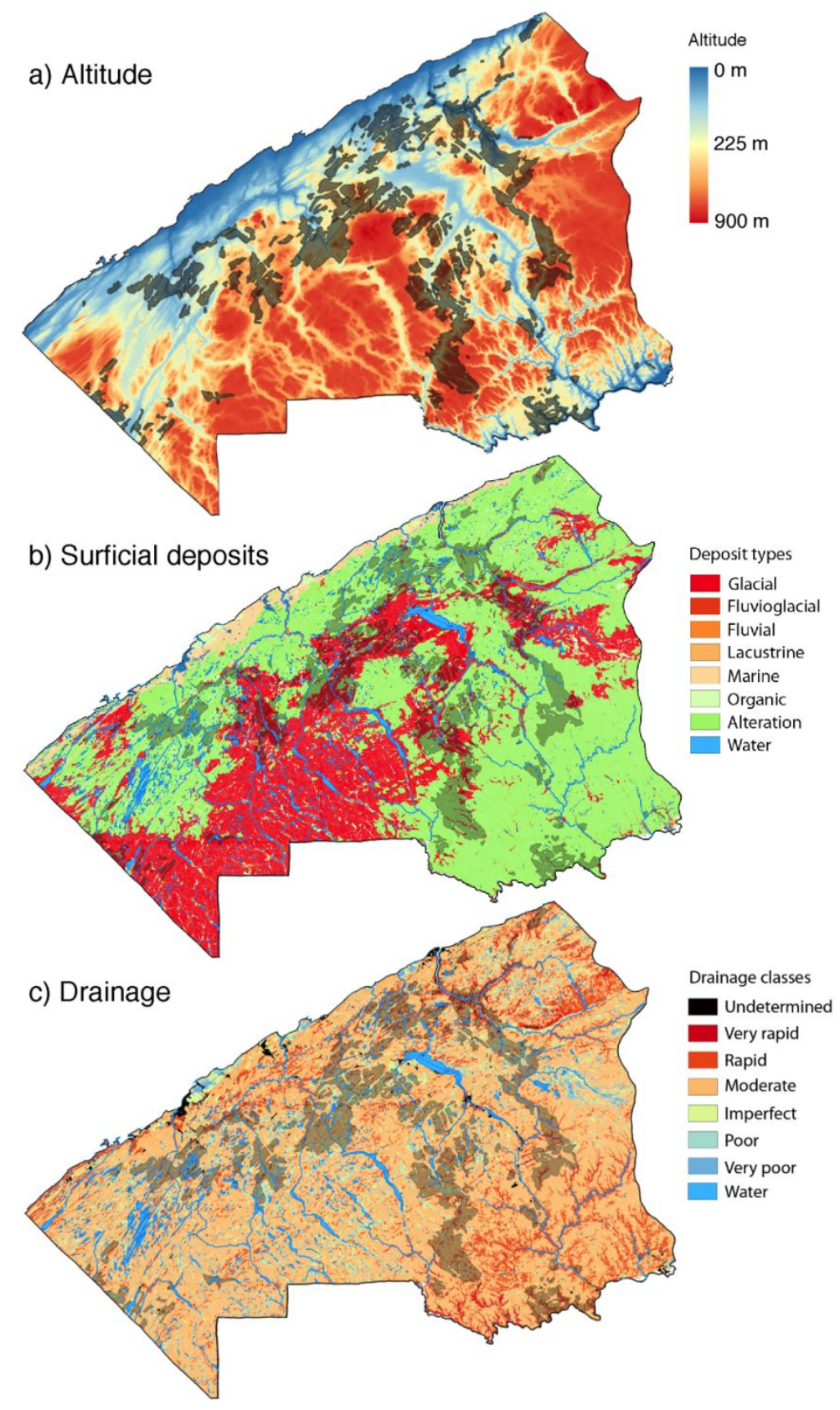

Appendix S1. Maps of altitude (a), surficial deposits (b) and drainage classes (c) across the study area. Shaded 3 gray areas correspond to all fires (ancient plus recent). 
Supporting information to the paper

Terrail, R. et al. Effects of $20^{\text {th }}$-century settlement fires on landscape structure and forest composition in Eastern Québec, Canada. Journal of Vegetation Science

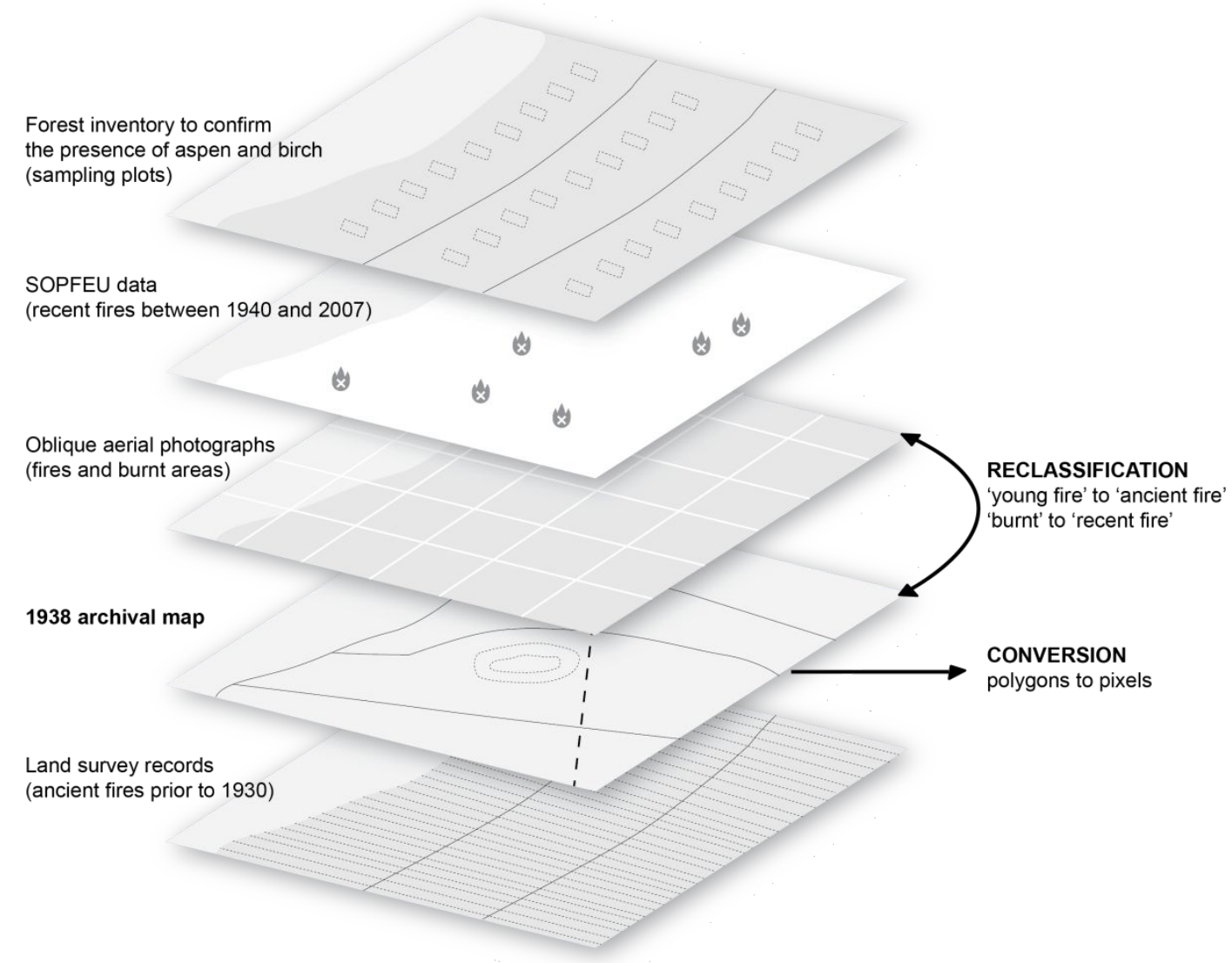

6 Appendix S2. Diagram showing the temporal and conceptual relationships between the georeferenced layers used in this study. 


\section{Supporting information to the paper}

Terrail, R. et al. Effects of $20^{\text {th }}$-century settlement fires on landscape structure and forest composition in Eastern Québec, Canada. Journal of Vegetation Science

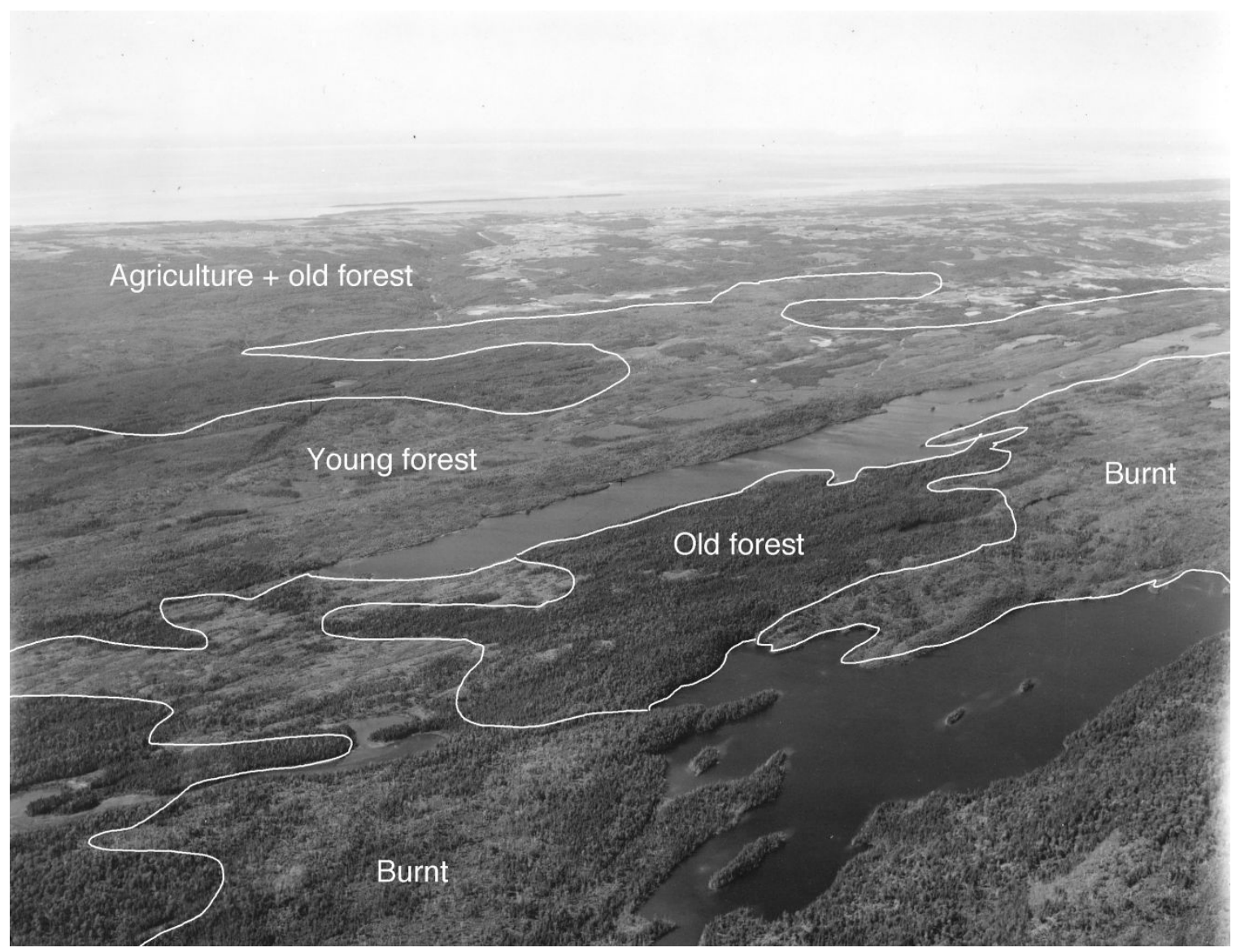

9 Appendix S3. Archive photo illustrating the landscape classes mapped from the 1938 aerial survey in the hinterland

10 of the Lower St. Lawrence region (Québec, Canada). "Young forest" polygons consistently correspond to fires with

11 very similar appearance and age as "burnt" polygons, with typical unburned islands and irregular contours. In fact,

12 the "burnt" and "young forest" areas displayed in the photo burned during the same fire event in 1923. The St.

13 Lawrence River is in the background. The oblique photo was taken during the aerial survey and was then used to

14 validate the mapping of landscape classes (Bibliothèque et Archives nationales du Québec, E21, P96). 
Supporting information to the paper

Terrail, R. et al. Effects of $20^{\text {th }}$-century settlement fires on landscape structure and forest composition in Eastern Québec, Canada. Journal of Vegetation Science

16 Appendix S4. Validation of the mapped ecoforest polygons dominated by Populus and Betula taxa from the 17 associated field plots of the Third Decennial Inventory of the Québec Ministry of Natural Resources. Plots are 18 circular units covering surfaces of 0.4 ha (MRNFQ 2007). Frequency: number (percent) of plots containing the 19 corresponding species for each polygon category. Mean stem density is averaged across all plots containing a given 20 species.

21

\begin{tabular}{lcccc}
\hline & \multicolumn{2}{c}{ "Populus" polygon } & \multicolumn{2}{c}{ "Betula" polygon } \\
\hline & Frequency & $\begin{array}{c}\text { Stem density } \\
(\mathrm{N} / \mathrm{ha})\end{array}$ & Frequency & $\begin{array}{c}\text { Stem density } \\
(\mathrm{N} / \mathrm{ha})\end{array}$ \\
\cline { 2 - 5 } All species & 444 & $1069 \pm 470$ & 807 & $920 \pm 457$ \\
Populus tremuloides & $354(79.7 \%)$ & $366 \pm 335$ & $123(15.2 \%)$ & $135 \pm 168$ \\
Populus balsamea & $65(14.6 \%)$ & $332 \pm 423$ & $10(1.2 \%)$ & $90 \pm 65$ \\
Betula papyrifera & $331(74.5 \%)$ & $181 \pm 206$ & $651(80.7 \%)$ & $259 \pm 257$ \\
Betula alleghaniensis & $53(11.9 \%)$ & $80 \pm 61$ & $482(49.8 \%)$ & $102 \pm 86$ \\
\hline
\end{tabular}


Supporting information to the paper

Terrail, R. et al. Effects of $20^{\text {th }}$-century settlement fires on landscape structure and forest composition in Eastern Québec, Canada. Journal of Vegetation Science
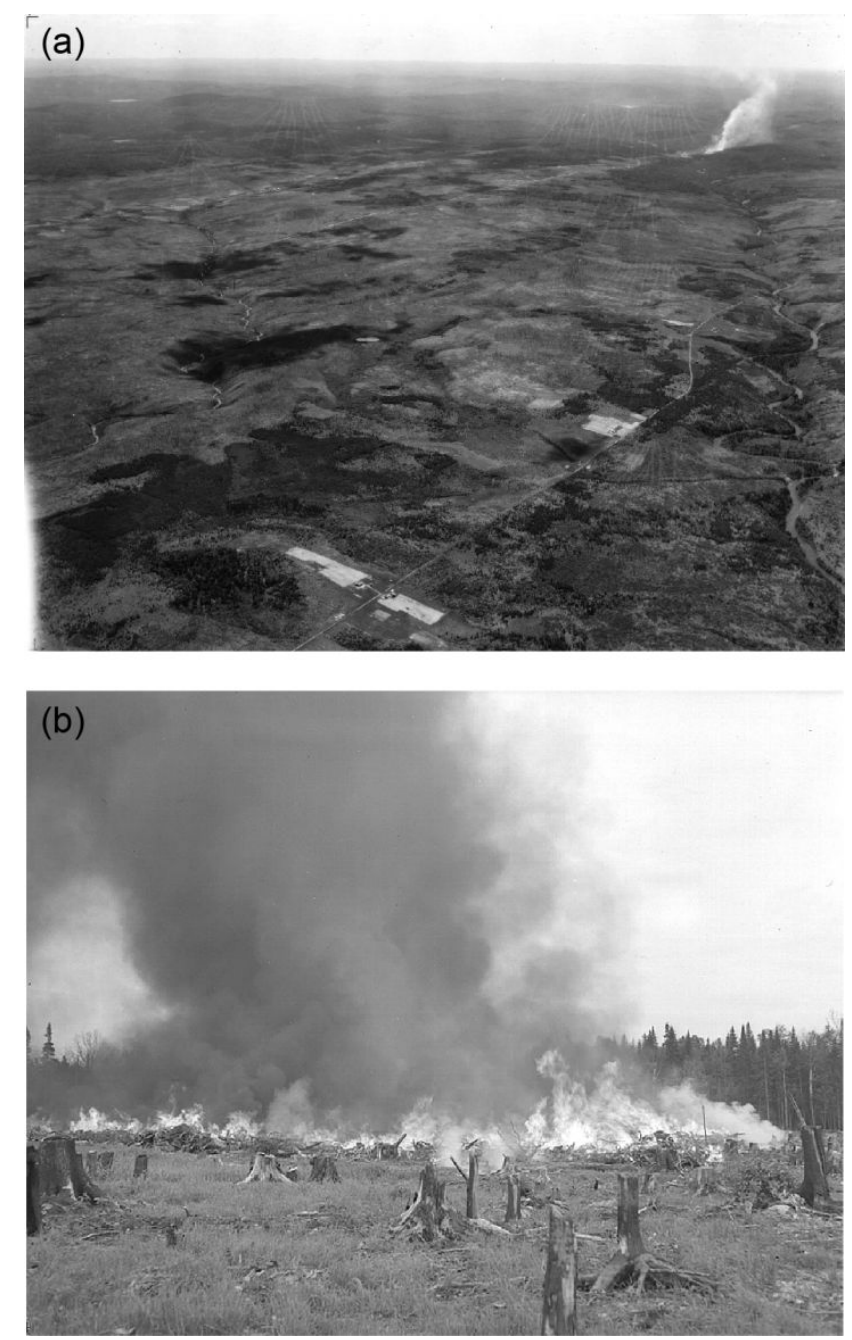

Appendix S5. Archive photos illustrating typical slash fires during the settlement in the hinterland of the St.

26 Lawrence region (Québec, Canada): (a) oblique aerial photograph taken at the time of the mapping of the study area

27 in 1938 (Bibliothèque et Archives nationales du Québec, E21, P112). Note the establishment of ribbon farms along 28 two range lines (front and background of the photo). The land between the two ranges were almost completely burnt 29 shortly before the photograph. An active slash fire is visible on the top-right; (b) slash fire in 1944 at Saint-Marcellin 30 (photo by Paul Carpentier, Bibliothèque et Archives nationales du Québec, E6, S7, SS1, P21326). 
Supporting information to the paper

Terrail, R. et al. Effects of $20^{\text {th }}$-century settlement fires on landscape structure and forest composition in Eastern Québec, Canada. Journal of Vegetation Science

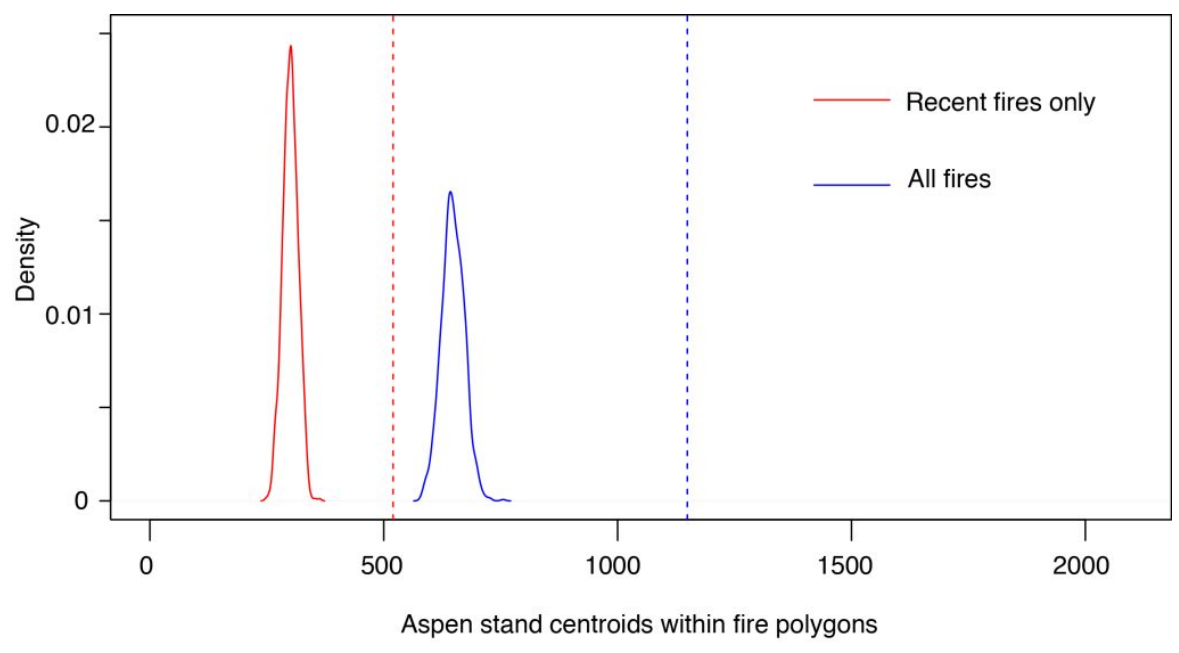

Aspen stand centroids within fire polygons

32 Appendix S6. Comparison of simulated and observed numbers of aspen stand centroids tallied within all fire 33 polygons (as shown in Fig 3c; blue curve) with the number tallied when considering only the "recent fire" class.

34 Frequency distributions indicate the number of aspen stand centroids $(n=3,586)$ included within fire polygons over

351,000 random permutations. Vertical dotted lines refer to the number of stands actually recorded within each fire

36 polygon dataset, which are far greater than the numbers observed during each of the 1000 random permutations. The

37 conclusion of a strong connection between aspen stands and fire polygons thus holds whatever the fire dataset

38 considered. 
Supporting information to the paper

Terrail, R. et al. Effects of $20^{\text {th }}$-century settlement fires on landscape structure and forest composition in Eastern Québec, Canada. Journal of Vegetation Science

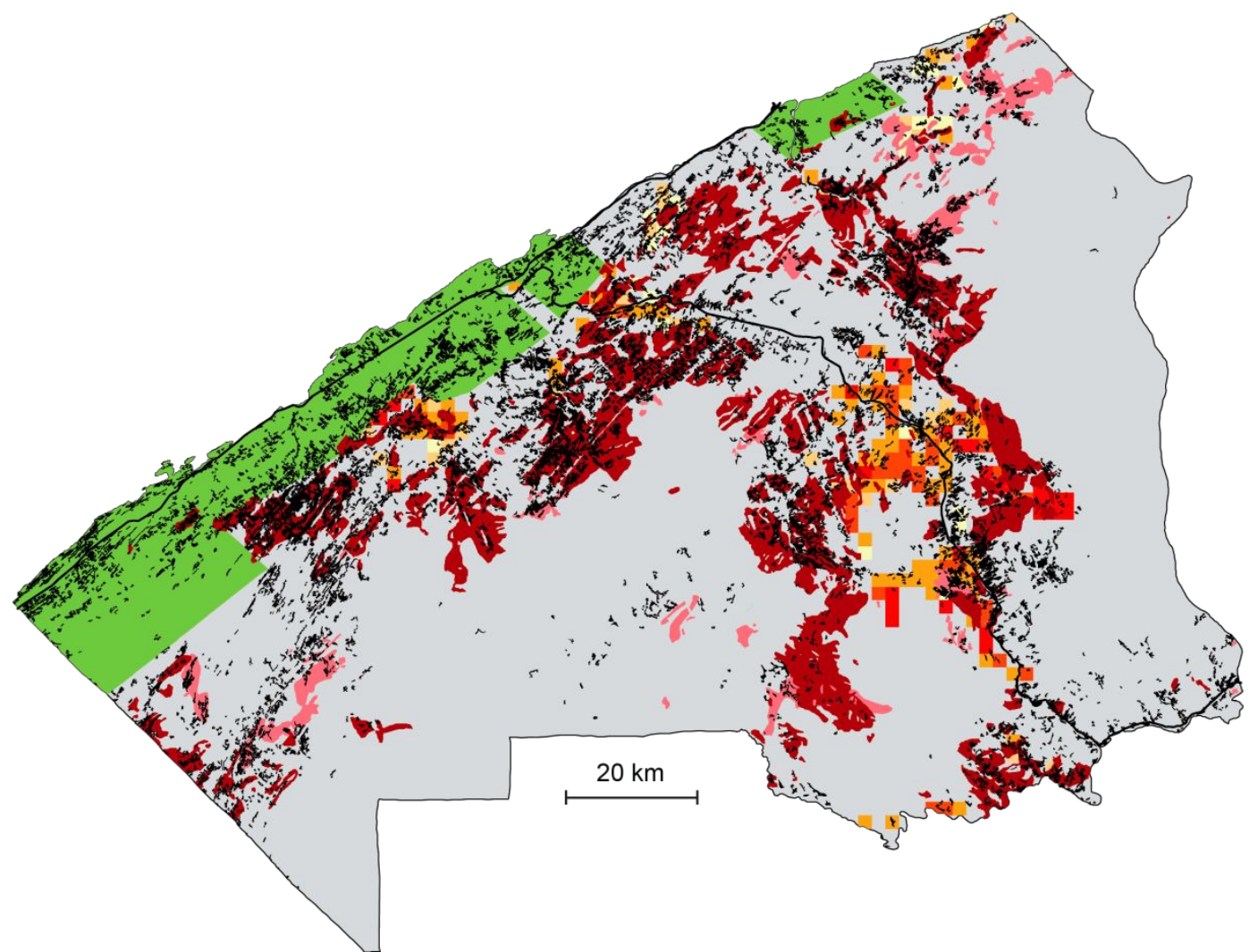

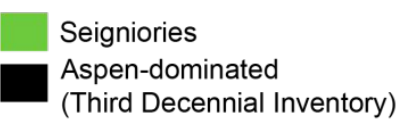

SOPFEU fire (1940-2007)

1938-map "fire" class

- Railway
Fire records from early land surveys (1820-1930) ( $\%$ of the surveys observations)
1 to $5 \%$
5 to $10 \%$
10 to $30 \%$
30 to $50 \%$
50 to $75 \%$
75 to $100 \%$

40 Appendix S7. The spatial distribution of fire, aspen and birch in the Lower St. Lawrence region (Québec, Canada)

41 (ecoforest maps from the Ministry of Natural Resources, MRNQ 2000a) in relation with the landscape structure 42 classes of the 1938 map. 